\title{
E-Learning For Kids Education About Corona Virus Pada Sdn 01 Duren Tiga
}

\author{
Tri Juninisvianty ${ }^{1}$, Daniati Uki Eka Saputri ${ }^{2}$, Nurul Khasanah ${ }^{3}$, Eko Arif Riyanto ${ }^{4}$, F Lia Dwi \\ Cahyanti $^{5}$, Syarah Seimahuira ${ }^{6}$, Agus Salim ${ }^{7}$, Didi Rosiyadi ${ }^{8}$ \\ 1,2,4,8Program Studi IImu Komputer,STMIK Nusa Mandiri Jakarta \\ $3,5,6,7$ Universitas Bina Sarana Informatika \\ 114002341@nusamandiri.ac.id, 2daniati.due@nusamandiri.ac.id, 3nurul.nuk@bsi.ac.id, \\ 414002353@nusamandiri.ac.id, 5flia.fdc@bsi.ac.id, ${ }^{5}$ syarah.yrs@bsi.ac.id, \\ 7agus.asm@bsi.ac.id, ${ }^{8}$ didi@nusamandiri.ac.id
}

\begin{abstract}
E-Learning For Kids Education about Corona Virus (EduCovid-19) is an e-learning website for elementary school students to be able to bridge teachers, parents and students in providing correct information about the spread, danger, and handling of corona virus outbreaks. In addition, this website is equipped with Thematic material that students get at school. By implementing a primary school curriculum for thematic lessons, it is hoped that it can adjust the learning system that is available in schools. The design of EduCovid-19 contains material in the form of education and exercises about Covid-19 and thematic lessons where in one of these materials there will be questions and answers as one of the interactive assessment methods for teachers. The method used in the design of this system is RAD and the research methods used in data collection are interviews, observation and case studies. By applying the learning system using EduCovid-19, it will be able to increase children's interest in the learning process that is currently underway, namely school from home and provide students with knowledge about the dangers and ways to overcome Covid-19.
\end{abstract}

\section{Keywords: Elearning, School, Covid-19, EduCovid-19}

Abstrak: E-Learning For Kids Education about Corona Virus (EduCovid-19) merupakan website elearning bagi pelajar sekolah dasar untuk dapat menjembatani guru, orang tua dan siswa dalam memberikan informasi yang benar seputar penyebaran, bahaya, dan penangan terkait wabah virus corona. Selain itu, di website ini dilengkapi dengan materi Tematik yang siswa dapatkan di sekolah. Dengan menerapkan kurikulum sekolah dasar pelajaran tematik, diharapkan dapat menyesuaikan sistem pembelajaran yang terdapat di sekolah. Perancangan EduCovid-19 ini berisi materi-materi berupa edukasi serta latihan soal seputar Covid-19 dan pelajaran tematik dimana dalam salah satu materi tersebut akan ada tanya jawab sebagai salah satu metode penilaian interaktif bagi para guru. Dalam perancangan sistem ini menggunakan metode RAD dan metode penelitian yang digunakan dalam pengumpulan data yaitu wawancara, observasi dan studi kasus. Dengan penerapan sistem pembelajaran menggunakan EduCovid-19 nantinya mampu meningkatkan ketertarikan anak dalam proses pembelajaran yang saat ini sedang berlangsung yaitu school from home dan memberikan pengetahuan kepada siswa mengenai bahaya dan cara menghindari serta mengatasi Covid-19.

Kata kunci: Elearning, Sekolah, Covid-19, EduCovid-19

(i) This is an open access article distributed under the Creative Commons Attribution License, which permits unrestricted use, distribution, and reproduction in any medium, provided the original work is properly cited. (02019 by author and IJSE-Indonesian Journal on Software Engineering.

\section{A. PENDAHULUAN}

World Health Organization menetapkan virus Covid-19 sebagai pandemi yang menjangkit berbagai negara dalam waktu yang bersamaan termasuk Indonesia. Kebijakan pemerintah RI memberlakukan physical distancing yang diharapkan dapat memperlambat laju penularan Covid-19. Kebijakan tersebut berdampak kepada banyak sektor salah satunya adalah dunia pendidikan khususnya untuk sekolah. Peralih fungsi dari pertemuan tatap muka menjadi 
pembelajaran berbasis elektronik, khususnya untuk jenjang Sekolah Dasar (SD) mengalami kendala karena belum siap menghadapi perubahan sistem belajar tersebut. Dari hasil wawancara yang dilakukan secara online pada orang tua siswa Sekolah Dasar, banyak siswa yang menganggap kondisi saat ini diberlakukan libur, bukan untuk pengalihan sistem pembelajaran. Banyak orang tua peserta didik yang menghadapi kesulitan untuk memberikan penjelasan terkait masalah tersebut. Oleh karena itu, untuk menjembatani antara guru, orang tua, dan siswa untuk melakukan proses pemberian informasi dari orang tua ke anak menjadi lebih baik terkait perubahan sistem belajar tersebut, maka dibutuhkan sebuah media untuk belajar dan mengajar yang lebih fleksibel. Rosenberg dalam [Elyas, 2018] menekankan bahwa e-learning merujuk pada penggunaan teknologi internet untuk mengirimkan serangkaian solusi yang dapat meningkatkan pengetahuan dan keterampilan.

\section{B. TINJAUAN PUSTAKA}

Penerapan metode Rapid Application Development dalam sistem Informasi Educovid-19 yaitu dengan membagi pekerjaan sesuai dengan tahapannya dan dikerjakan tim yang telah ditentukan sesuai dengan time table atau jadwal yang sudah di rencanakan. Model ini melibatkan tim dalam setiap tahapannya dan dibagi menjadi tim-tim kecil yang kemudian akan mendapatkan tugas untuk mengerjakan di setiap tahapan yang sudah direncanakan, namun berbeda sesuai dengan pembagian modul sistem. Dalam penggunakan metode RAD sistem yang dikembangkan lebih cepat tersampaikan ke user dan tidak diperlukan dalam menunggu fitur yang lain terselesaikan.

\section{Internet}

Lani sidarta tahun 1996 memberikan gambaran definisi internet. Secara fisikteknologi ini adalah wujud dari perpaduan jaringan komputer-komputer dunia, internet perlu juga dipandang serius sebagai gudang informasi. Internet menjadi salah satu sumber daya informasi yang sangat potensial untuk mempermudah sistem kehidupan. "internet (interconnected network) adalah jaringan komputer yang menghubungkan antar jaringan secara global, internet dapat juga disebut jaringan dalam suatu jaringan yang luas". Sedangkan menurut Nugroho dalam [Susan, Melan \& Janti, 2017] mengemukakan bahwa internet adalah solusi jaringan yang dapat menghubungkan banyak jaringan lokal yang ada di suatu Daerah, Kota dan Negara.

\section{Teknologi Website}

a. Website

[Supriyanta and Nurhayati, 2018] Website atau disingkat web dapat diartikan sekumpulan halaman yang terdiri dari beberapa laman yang berisi informasi dalam bentuk data digital baik berupa text, gambar video, audio, dan animasi lainnya yang disediakan melalui jalur koneksi internet.

b. HTML

HTML (Hyper Text Markup Language) adalah bahasa markup yang umum digunakan untuk membuat halaman web. Sebenarnya HTML bukanlah sebuh bahasa pemrograman. Apabila ditinjau dari namanya, HTML merupakan bahasa markup atau penandaan terhadap sebuah dokumen teks. Tanda tersebut digunakan untuk menentukan format atau style dari teks yang ditandai (Suyanto, 2007)

c. Bahasa Pemrograman

Kadir dalam [Susan, Melan \& Janti, 2017] mengemukakan bahwa: Yang dimaksud dengan program adalah kumpulan instruksi yang digunakan untuk mengatur komputer agar melakukan suatu tindakan tertentu. Tanpa program, komputer sesungguhnya tidak dapat berbuat apa-apa. Itulah sebabnya sering dikatakan bahwa komputer mencangkup tiga aspek penting, berupa perangkat keras (hardware), perangkat lunak (software) yang dalam hal ini berupa program, dan perangkat akal (brainware) atau orang yang berperan terhadap operasi komputer maupun pengembangan perangkat lunak. (Abdulloh,2018) mengemukakan bahwa : Pemrograman sendiri dapat diartikan sebagai proses atau cara pembuatan program menggunakan bahasa pemrograman. Adapun bahasa pemrograman merupakan bahasa yang digunakan untuk Pelangganikan intruksi kepada komputer sehingga komputer dapat memproses data dan menampilkan informasi sesuai yang dikehendaki oleh pemrogram. 
d. MySQL Database

MySQL ( MY Structure Query Language ) adalah salah h satu Basis Data Management System ( DBMS ) dari sekian banyak DBMS seperti Oracle, MS SQL, Postagre SQL, dan lainnya. MySQL berfungsi untuk mengolah Basis Data menggunakan bahasa SQL. MySQL bersifat open source sehingga kita bisa menggunakannya secara gratis. Pemprograman PHP juga sangat mendukung atau mensupport dengan Basis Data MySQL. Sedangkan MySQL merupakan Basis Data yang paling digemari dikalangan programmer web, dengan alasan bahwa program ini merupakan Basis Data yang sangat kuat dan cukup stabil untuk digunakan sebagai media penyimpanan data. Sebagai sebuah Basis Data server yang mampu untuk memenajemen Basis Data dengan baik, mysql terhitung merupakan Basis Data yang paling digemari dan paling banyak digunakan dibanding Basis Data lainnya. Selain mysql masih terdapat beberapa jenis Basis Data server yang juga memiliki kemampuan yang juga tidak bisa dianggap enteng, Basis Data itu adalah Oracle dan PostgreSQL. [Umagapi and Ambarita, 2018]

e. Entity Relationship Diagram (ERD)

$E R D$ merupakan diagram yang menunjukan tentang adanya informasi dibuat, disimpan dan digunakan dalam bisnis. [Supriyanta and Nurhayati, 2018]

f. Logical Relatioanship Structure (LRS)

Logical Record Structure adalah hasil dari permodelan Entity Relationship beserta atribut sehingga dapat terlihat hubungan yang ada antar entitas. [Supriyanta and Nurhayati, 2018]

g. Data Flow Diagram (DFD)

\section{Elearning}

Rosenberg menekankan dalam [Elyas, 2018] bahwa e-learning merujuk pada penggunaan teknologi internet untuk mengirimkan serangkaian solusi yang dapat meningkatkan pengetahuan dan keterampilan. Hal ini sesuai dengan pemaparan yang berupa penekanana menekankan penggunaan internet dalam pendidikan sebagai hakekat elearning [Komarudin, 2017]. Bahkan Onno W. Purbo menjelaskan bahwa istilah "e" atau singkatan dari elektronik dalam e-learning digunakan sebagai istilah untuk segala teknologi yang digunakan untuk mendukung usaha-usaha pengajaran lewat teknologi elektronik internet.

\section{RAD (Rapid Application Development)}

Rapid Aplication Development (RAD) adalah sebuah proses perkembangan perangkat lunak sekuensial linier yang menekankan siklus perkmebangan dalam waktu singkat. RAD menggunakan metode iterative(berulang) dalam mengembangkan sistem dimana working model (model bekerja) sistem dikonstruksikan di awal tahap pengembangan dengan tujuan menetapkan kebutuhan (requirement) pengguna dan selanjutnya disingkirkan.

\section{METODE PENELITIAN}

Metode pengembangan perangkat lunak yang digunakan yaitu metode Rapid Application Development (RAD), menurut [Larasati and Masripah, 2017] tahapan-tahapan dalam metode ini dapat dijabarkan sebagai berikut :

a) Requirement planning: user dan analyst melakukan pertemuan untuk mengidentifikasi tujuan dari sistem dan kebutuhan informasi untuk mencapai tujuan. Pada tahap ini merupakan hal terpenting yaitu adanya keterlibatan dari kedua belah pihak.

b) Design System: pada tahap ini keaktifan user yang terlibat menentukan untuk mencapai tujuan karena pada proses ini melakukan proses desain dan melakukan perbaikan perbaikan apabila masih terdapat ketidaksesuaian desain antara user dan analyst. Seorang user dapat langsung memberikan komentar apabila terdapat ketidaksesuaian pada desain, merancang sistem dengan mengacu pada dokumentasi kebutuhan user yang sudah dibuat pada tahap sebelumnya. Keluaran dari tahapan ini adalah spesifikasi software yang meliputi organisasi sistem secara umum, struktur data dan yang lain.

c) Implementation: pada tahapan ini adalah tahapan dimana programmer yang mengembangkan desain suatu program yang telah disetujui oleh user dan analyst. Sebelum diaplikasikan pada suatu organisasi terlebih dahulu dilakukan proses pengujian terhadap program tersebut apakah ada kesalahan atau tidak. Proses ditahap ini user akan memberikan masukkan pada sistem yang sedang dibuat serta mendapat persetujuan terhadap sistem tersebut. 
Pada Penelitian ini menggunakan metode RAD dalam model perangkat lunaknya. Berikut adalah langkah dalam metode RAD:

a. Rencana Kebutuhan (Requirement Planning) Pada langkah ini, dilakukan penelaahan terhadap tujuan dari sistem belajar berbasis Elearning yang akan dirancang, dan melakukan perincian kebutuhan dari rencana yang dirancang untuk mencapai suatu tujuan, hal-hal yang harus diperhatikan dalam tahapan Requirement Planning yaitu adanya keterlibatan dari pihak-pihak yang terkait.

b. Proses Rancangan Sistem (Design Sistem) IRAD Design Workshop. Pada tahapan Perancangan Sistem akan melakukan tahapan Rancangan sistem pembelajaran yang berbasis E-learning dan akan dilakukan perbaikan jika terdapat rancangan yang tidak seusai dengan keinginan user. Pada tahap ini maka dibutuhkan komunikasi yang aktif dengan user yang terlibat agar dapat sesuai dengan tujuan dari rancangan, karena user dapat memberikan masukan langsung jika terdapat hal-hal yang tidak sesuai pada alur proses dan rancangan, rancangan sistem belajar yang berbasis E-learning sesuai dengan dokumentasi dari kebutuhan user yang telah dibuat pada langkah sebelumnya. Pada tahapan ini akan menghasilkan spesifikasi dari software yang meliputi organisasi sistem belajar berbasis E-learning secara umum, struktur data, dan proses lainnya.

c. Implementasi (Implementation) adalah sebuah rancangan sistem belajar yang berbasis Elearning telah disetujui oleh user, maka pada langkah ini programmer akan membangun sistem pembelajaran yang berbasis E-learning. Setelah proses pembuatan maka akan dilakukan pengecekan terhadap proses dari alur pembelajaran yang berbasis E-learning tersebut apakah terjadi kesalahan atau tidak sebelum digunakan. Pada Langkah ini maka user akan memberikan masukkan dari sistem yang sudah dibuat serta melakukan persetujuan jika sudah tidak ada lagi kesalahan

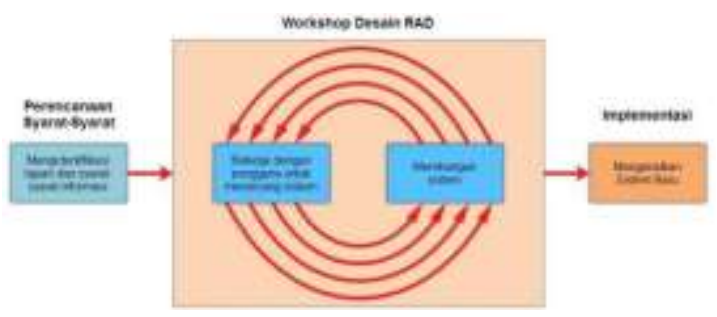

Gambar 1. Rapid Application Development

D. HASIL DAN PEMBAHASAN

1) Entity Relationship Diagram

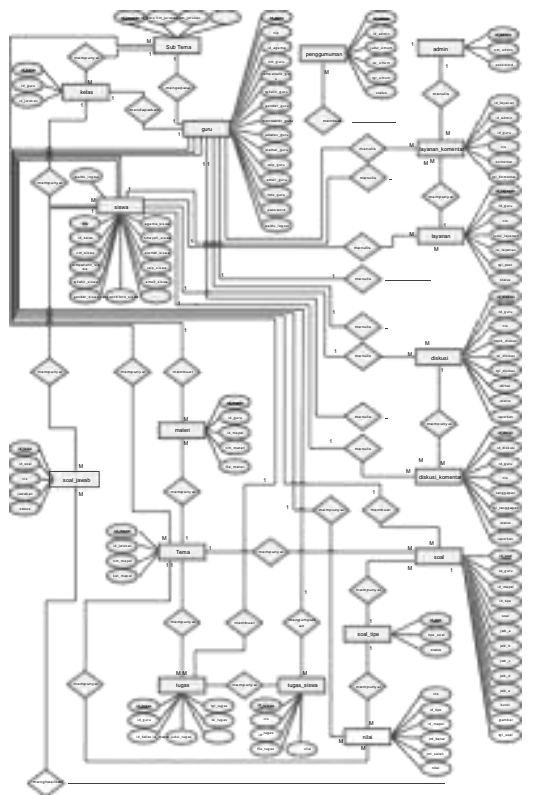

Gambar 2. Entity Relationship Diagram 
Dalam pembuatan rancangan database setelah di gambarkan dalam bentuk ERD (gambar 2), kemudian digambarkan dalam bentuk LRS, dengan harapan rancangan basis data yang ada dapat lengkap memenuhi sistem.

\section{2) Logical Relational Structure (LRS)}

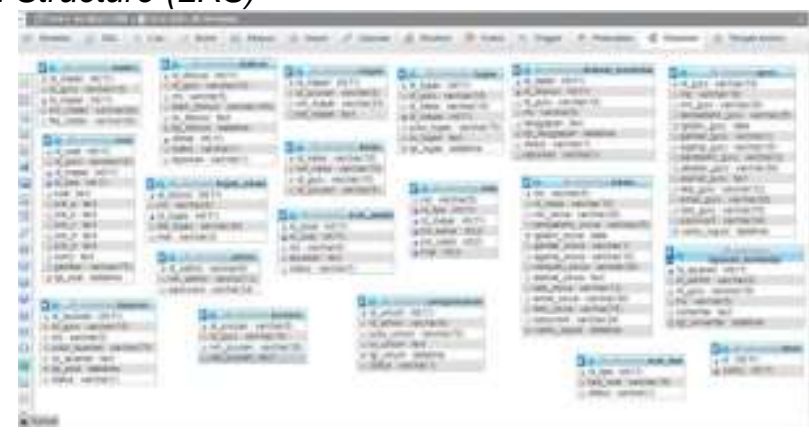

Gambar 3. Logical Relational Structure

Dengan berdasarkan LRS (Gambar 3) yang telah dibuat kemudian dijadikan acuan untuk membuat database dengan aplikasi yang dipilih

3) Data Flow Diagram

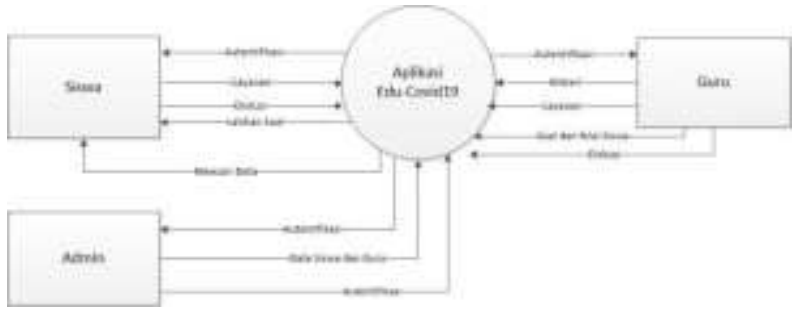

Gambar 4. Data Flow Diagram

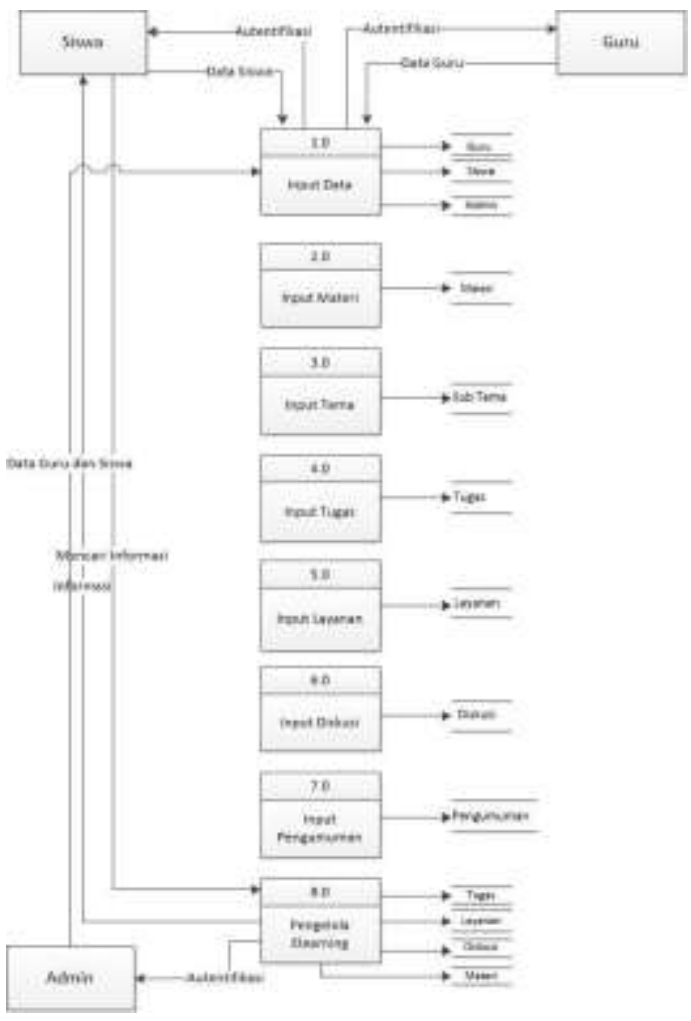

Gambar 5. Data Flow Diagram Level 0 
IJSE - Indonesian Journal on Software Engineering, Vol.6, No.2, Desember 2020, 250-260

4) Spesifikasi File

a. Spesifikasi File Tabel Admin

Tabel 1. Spesifikasi File Tabel Admin

\begin{tabular}{|c|c|c|c|c|}
\hline Akronim & $\begin{array}{c}\text { Elemen } \\
\text { Data }\end{array}$ & Tipe & Lenght & Ket \\
\hline id_admin & Id Admin & char & 6 & PK \\
\hline nm_admin & $\begin{array}{c}\text { Nama } \\
\text { Admin }\end{array}$ & varchar & 13 & \\
\hline password & Password & varchar & 32 & \\
\hline
\end{tabular}

b. Spesifikasi File Tabel Guru

Tabel 2. Spesifikasi File Tabel Guru

\begin{tabular}{|c|c|c|c|c|}
\hline Akronim & $\begin{array}{c}\text { Elemen } \\
\text { Data }\end{array}$ & Tipe & Lenght & Ket \\
\hline id_guru & Id Guru & char & 10 & $P K$ \\
\hline nip & $\begin{array}{l}\text { No Induk } \\
\text { Pegawai }\end{array}$ & char & 18 & \\
\hline nm_guru & Nama Guru & varchar & 30 & \\
\hline tempatlahir_guru & $\begin{array}{c}\text { Tempat } \\
\text { Lahir }\end{array}$ & varchar & 25 & \\
\hline tgllahir_guru & $\begin{array}{c}\text { Tanggal } \\
\text { Lahir }\end{array}$ & date & 10 & \\
\hline gender_guru & Gender & char & 1 & \\
\hline agama_guru & Agama & varchar & 10 & \\
\hline pendakhir_guru & $\begin{array}{c}\text { Pendidikan } \\
\text { Akhir }\end{array}$ & varchar & 3 & \\
\hline jabatan_guru & Jabatan & varchar & 30 & \\
\hline alamat_guru & Alamat & text & 100 & \\
\hline telp_guru & $\begin{array}{l}\text { Nomor } \\
\text { Telepon }\end{array}$ & varchar & 13 & \\
\hline email_guru & $\begin{array}{c}\text { Alamat } \\
\text { Email }\end{array}$ & varchar & 30 & \\
\hline foto_guru & Foto & varchar & 30 & \\
\hline password & Password & varchar & 32 & \\
\hline waktu_logout & $\begin{array}{l}\text { Terakhir } \\
\text { Logout }\end{array}$ & datetime & 19 & \\
\hline
\end{tabular}

c. Spesifikasi File Tabel Siswa

Tabel 3. Spesifikasi File Tabel Siswa

\begin{tabular}{|l|l|l|l|l|}
\hline Akronim & Elemen Data & Tipe & $\begin{array}{l}\text { Leng } \\
\text { ht }\end{array}$ & $\begin{array}{l}\text { Ke } \\
\text { t }\end{array}$ \\
\hline Nis & Nomor Induk & char & 5 & PK \\
\hline id_kelas & Id Kelas & integer & 11 & FK \\
\hline nm_siswa & Nama Siswa & varchar & 30 & \\
\hline $\begin{array}{l}\text { tempatlahir_si } \\
\text { swa }\end{array}$ & Tempat Lahir & varchar & 25 & \\
\hline tgllahir_siswa & Tanggal Lahir & date & 10 & \\
\hline gender_siswa & Gender & Char & 1 & \\
\hline agama_siswa & Agama & varchar & 10 & \\
\hline nmayah_siswa & NamaAyah & varchar & 30 & \\
\hline telp_siswa & Nomor Telepon & varchar & 13 & \\
\hline email_siswa & Alamat Email & varchar & 30 & \\
\hline foto_siswa & Foto & varchar & 30 & \\
\hline Password & Password & varchar & 32 & \\
\hline waktu_logout & Terakhir Logout & $\begin{array}{l}\text { datetim } \\
\text { e }\end{array}$ & 19 & \\
\hline
\end{tabular}


d. Spesifikasi File Tabel Soal

Tabel 4. Spesifikasi File Tabel Soal

\begin{tabular}{|l|l|l|l|l|}
\hline Akronim & Elemen Data & Tipe & $\begin{array}{l}\text { Leng } \\
\text { th }\end{array}$ & Ket \\
\hline id_soal & Id Soal & integer & 11 & $\begin{array}{l}\text { PK, } \\
\text { Al }\end{array}$ \\
\hline id_guru & Id Guru & char & 10 & FK \\
\hline id_tema & Id Mata Pelajaran & integer & 11 & FK \\
\hline id_tipe & Id Tipe & integer & 11 & FK \\
\hline Soal & Soal & text & 1000 & FK \\
\hline jwb_a & Jawaban A & text & 600 & FK \\
\hline jwb_b & Jawaban B & text & 600 & FK \\
\hline jwb_c & Jawaban C & text & 600 & FK \\
\hline jwb_d & Jawaban D & text & 600 & FK \\
\hline jwb_e & Jawaban E & text & 600 & FK \\
\hline Kunci & Kunci Jawaban & text & 600 & FK \\
\hline Gambar & Gambar Soal & varchar & 50 & FK \\
\hline tgl_soal & Tanggal Dibuat & datetime & 19 & FK \\
\hline
\end{tabular}

5) Implementasi Sistem dan Hasil

a. Halaman utama

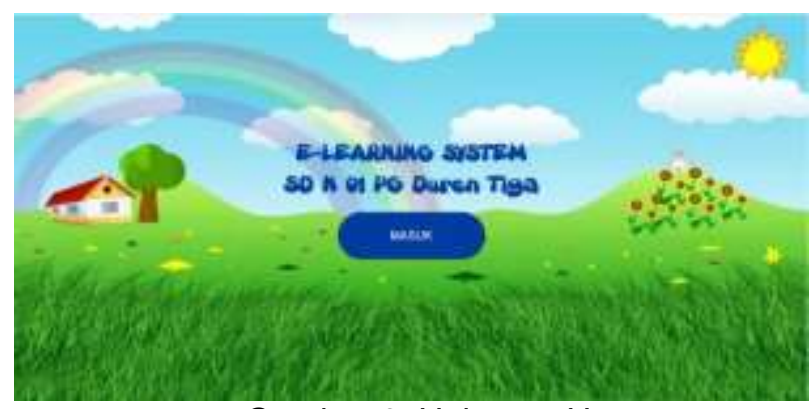

Gambar 6. Halaman Utama

b. Halaman Login

Halaman login merupakan halaman pertama sebelum masuk dalam halaman utama masing masing user. Seorang user harus memasukan id user dan password ke dalam form yang sudah disediakan.

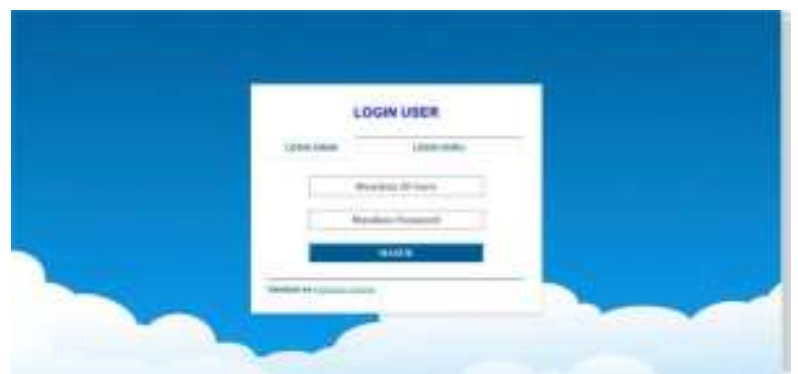

Gambar 7. Halaman Login 
IJSE - Indonesian Journal on Software Engineering, Vol.6, No.2, Desember 2020, 250-260

c. Halaman index admin

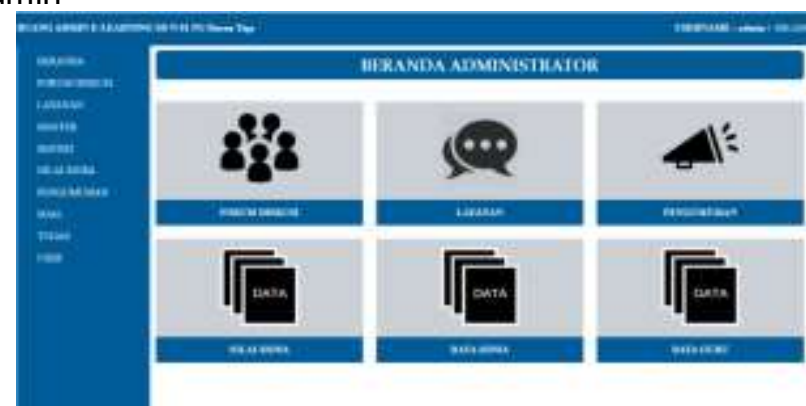

Gambar 8. Index Admin

d. Halaman index guru

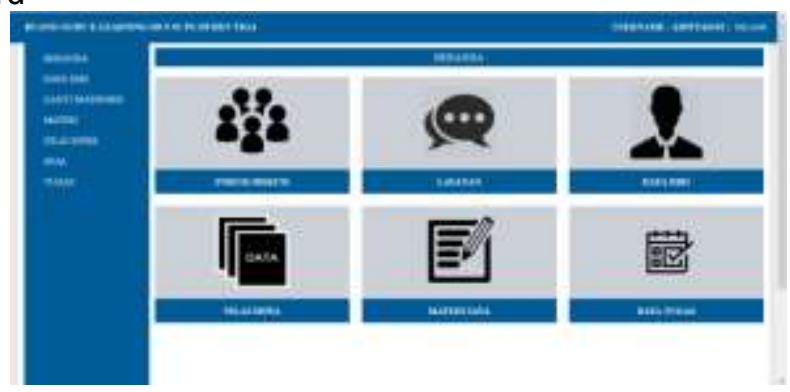

Gambar 9. Index Guru

e. Halaman index siswa

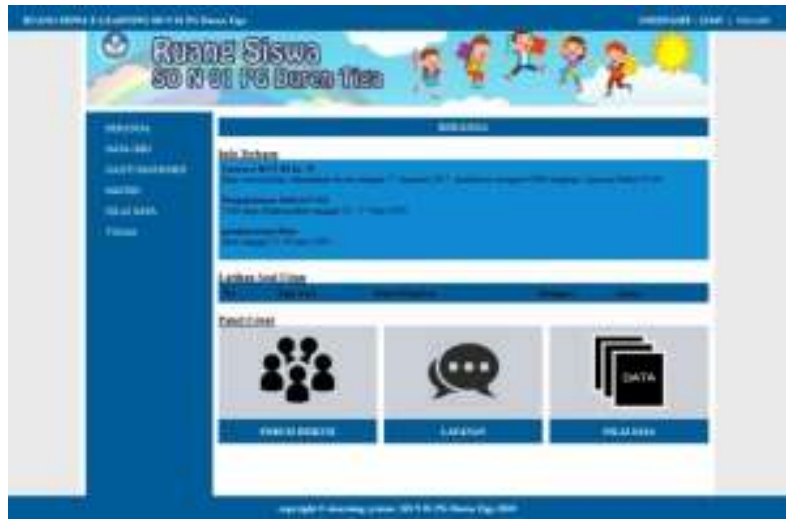

Gambar 10. Index Siswa

f. Halaman soal latihan siswa

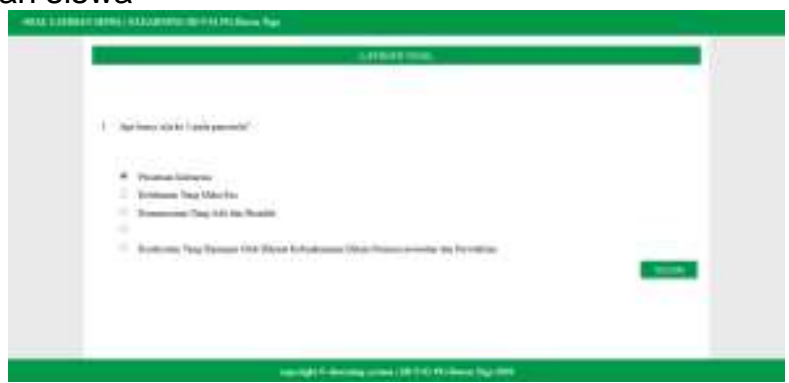

Gambar 11. Soal latihan siswa

g. Pengujian Unit

Tabel 5. Pengujian Unit

\begin{tabular}{|c|c|c|c|c|}
\hline No & $\begin{array}{c}\text { Skenario } \\
\text { Pengujian }\end{array}$ & Test Case & $\begin{array}{l}\text { Hasil Yang } \\
\text { Diharapkan }\end{array}$ & $\begin{array}{c}\text { Hasil } \\
\text { Pengujian }\end{array}$ \\
\hline 1 & Klik link masuk & Klik & Sistem & Sesuai \\
\hline
\end{tabular}




\begin{tabular}{|c|c|c|c|c|}
\hline & pada front page & masuk & $\begin{array}{lr}\text { mengarahkan } & \text { ke } \\
\text { halaman login siswa } \\
\text { dan guru. }\end{array}$ & Harapan \\
\hline 2 & $\begin{array}{l}\text { Klik link forum } \\
\text { diskusi }\end{array}$ & $\begin{array}{ll}\text { Klik } & \text { link } \\
\text { forum } & \\
\text { diskusi } & \end{array}$ & $\begin{array}{lr}\text { Sistem } & \text { akan } \\
\text { mengarahkan } & \text { ke } \\
\text { halaman login } & \text { siswa } \\
\text { dan guru. } & \end{array}$ & $\begin{array}{l}\text { Sesuai } \\
\text { Harapan }\end{array}$ \\
\hline 3 & $\begin{array}{l}\text { Klik link disini } \\
\text { pada download } \\
\text { materi }\end{array}$ & $\begin{array}{l}\text { Klik link } \\
\text { download } \\
\text { materi }\end{array}$ & $\begin{array}{lr}\text { Sistem } & \text { akan } \\
\text { mengarahkan } & \begin{array}{r}\text { ke } \\
\text { halaman download } \\
\text { semua materi }\end{array}\end{array}$ & $\begin{array}{l}\text { Sesuai } \\
\text { Harapan }\end{array}$ \\
\hline 4 & $\begin{array}{l}\text { Klik link } \\
\text { panduan siswa } \\
\text { pada panduan } \\
\text { e-learning }\end{array}$ & $\begin{array}{l}\text { Klik } \\
\text { panduan } \\
\text { siswa }\end{array}$ & $\begin{array}{l}\text { Sistem akan } \\
\text { menampilkan panduan } \\
\text { siswa di tab baru }\end{array}$ & $\begin{array}{l}\text { Sesuai } \\
\text { Harapan }\end{array}$ \\
\hline 5 & $\begin{array}{lr}\text { Klik } & \text { link } \\
\text { panduan guru } \\
\text { pada download } \\
\text { panduan } e^{-} \\
\text {learning }\end{array}$ & $\begin{array}{l}\text { Klik } \\
\text { panduan } \\
\text { guru }\end{array}$ & $\begin{array}{l}\text { Sistem akan } \\
\text { menampilkan panduan } \\
\text { guru di tab baru }\end{array}$ & $\begin{array}{l}\text { Sesuai } \\
\text { Harapan }\end{array}$ \\
\hline 6 & $\begin{array}{l}\text { Klik } r \text { link } \\
\text { panduan siswa } \\
\text { pada download } \\
\text { panduan } e^{-} \\
\text {learning }\end{array}$ & $\begin{array}{l}\text { Klik } \\
\text { panduan } \\
\text { siswa }\end{array}$ & $\begin{array}{l}\text { Sistem akan } \\
\text { menampilkan panduan } \\
\text { siswa di tab baru }\end{array}$ & $\begin{array}{l}\text { Sesuai } \\
\text { Harapan }\end{array}$ \\
\hline
\end{tabular}

\section{E. KESIMPULAN}

Kesimpulan yang dapat diambil, sebagai berikut:

1. Melalui program Edu-covid19 mampu menjembatani guru dan orangtua untuk membantu siswa dalam pembelajaran online

2. Orangtua dapat dipermudahkan dalam mengedukasi anak mengenai pandemi covid-19 melalui materi yang disediakan guru.

Saran yang penulis berikan, antara lain:

1. Penulis menyarankan kepada SDN 01 Duren Tiga dapat memanfaatkan sistem e-learning ini.

2. Penulis menyarankan untuk pengembangan sistem ke depan, sistem e-learning ini dapat digunakan untuk semua kelas dan tingkatan serta dapat digunakan untuk semua mata pelajaran.

3. Penulis menyarankan dalam pengembangan sistem selanjutnya dapat menggunakan fitur yang lebih menarik dan animasi tambahan seperti game pembelajaran sehingga mampu menambah daya tarik siswa dalam belajar.

4. Menambah tingkat keamanan sistem untuk mencegah penyalagunaan data oleh pihak lain.

\section{REFERENSI}

Abdulloh, R. (2018). 7 in 1 Pemrograman Web Abdulloh, R. (2018). 7 in 1 Pemrograman Web untuk Pemula. In 7 in 1 Pemrograman Web untuk Pemula. In PT Elex Media Komputindo.

Aswati, S., \& Siagian, Y. (2016). Model Rapid Application Development Dalam Rancang Bangun Sistem Informasi Pemasaran Rumah (Studi Kasus: Perum Perumnas Cabang Medan. Sesindo, 317-324.

Elyas AH. 2018. Penggunaan Model Pembelajaran E-Learning Dalam Meningkatkan Kualitas Pembelajaran. J. War. 56: 1-11.

Komarudin R. 2017. Penerapan Sistem E-Learning Dalam Proses Pembelajaran Siswa. J. Bianglala Inform. 5: 57-65.

Larasati H, Masripah S. 2017. Analisa Dan Perancangan Sistem Informasi Pembelian Grc Dengan Metode Waterfall. J. Pilar Nusa Mandiri 13: 193-198. 
IJSE - Indonesian Journal on Software Engineering, Vol.6, No.2, Desember 2020, 250-260

Supriyanta, Nurhayati I. 2018. Sistem Informasi Penjualan Secara Online Studi Kasus Pada Mechin Petshop Yogyakarta. J. Netw. Secur. - Vol. 8 No 1 - 2018 8: 1-6.

Susan, Melan \& Janti S. 2017. Volume 5 No 1 - Mei 2017 Jurnal Bianglala Informatika bianglala.bsi.ac.id. Penerapan Sist. Invent. Sebagai Pemenuhan Kebutuhan Inf. Antar Bagian Berbas. Web Dengan Increm. Model 5: 14-20.

Umagapi D, Ambarita A. 2018. Sistem Informasi Geografis Wisata Bahari pada Dinas Pariwisata Kota Ternate. J. Ilm. Ilk. - Ilmu Komput. Inform. 1: 59-69.

Permana, P. I. (2013). Sistem Informasi Perpustakaan Sekolah Berbasis Web dengan Framework Codeigniter dan PostgreSQL. Skripsi, 2, 8-35. 